\title{
Ce ție nu-ți place altuia nu-i face: Despre regula de aur în pandemie
}

conf. univ. dr. Radu Rizoiu

Facultatea de Drept, Universitatea București

The ultimate in vanity

Exploiting their supremacy

I can't believe the things you say

I can't believe

I can't believe the price you pay

Nothing can save you

Metallica, ...And Justice for All, ,...And Justice for All” (1988)

Rezumat: Articolul pornește de la „regula de aur” descrisă de John Rawls și o aplică actualei situații de pandemie. Astfel, se menționează un caz real pentru a ilustra standardul dublu pe care tindem să-l aplicăm atunci când ne referim la acțiunile noastre față de când ne referim la acțiunile altora. Pretindem mereu celorlalți să respecte regulile, în timp ce noi ne considerăm suficient de inteligenți pentru a alege când este util să le respectăm și când nu. Această atitudine are un efect pregnant mai ales atunci când persoana care ignoră regulile face parte din autoritățile care le-au edictat. Articolul se referă la problema respectării regulii ca regulă și la nevoia de a decanta regulile pornind de la nevoile indivizilor (ceea ce înseamnă că trebuie să fie explicate publicului) mai degrabă decât să fie impuse ,, de la centru”.

Cuvinte-cheie: reguli, pandemie, datorie civică

\section{Do not do unto others what you don't want others to do unto you: On the golden rule during the pandemic}

Abstract: The paper develops on John Rawls 'golden rule' and applies it to the current pandemic situation. In doing so, it starts with the presentation of a trivia case to illustrate the double standard we tend to apply when it comes to our actions as compared to the others'. We always ask to others to obey the rules, while we consider ourselves smart enough to decide on a case by case basis. This kind of attitude has a special effect when the persons ignoring the rules are exactly those who issued them. The paper tries to address the concern that following the rules should be a way of life and, in the same time, to suggest that rules should emanate from bottom to top (meaning they need to have a reasonable explanation to the public) rather than being imposed from top to bottom.

Keywords: rules, pandemic, civic duty

La un moment dat am aflat „la a șaptea mână”, următoarea anecdotă. Într-o mică urbe de provincie, în care notabilitățile orașului alcătuiesc o mică elită de facto, o persoană cunoscută pe plan local („om de afaceri”) este diagnosticată cu Covid-19. „S-au mai păstrat puține file/Din cronica acelor zile" și nu mai știm dacă testul a fost unul impus de Guvern sau unul solicitat de 
„suspect” pentru a putea să plece în concediu în Grecia. Cert este că a existat un test pozitiv. Legenda spune că ,titularul” a negat tot timpul că ar fi „,deținătorul” virusului, de vreme ce nu prezenta simptome evidente. Una peste alta, persoana este internată în spitalul local (faptele aveau loc înainte de decizia Curții Constituționale). „Prin mijloace specifice”, însă, ,aranjează” să nu fie „,cazată” într-o secție de „,covizi”, ci într-un salon cochet dintr-o secție ,normală”.

Toate bune și frumoase până când, în așteptarea unui alt test, fatalitatea lovește precum un fulger (globular). În același salon cochet se internează o altă persoană ,suspectă” de Covid-19 (doar că noua „locatară” prezintă simptome mai „vocale” - tușește). Eroul nostru, mulțumit până atunci de ,aranjamentul” realizat (de tipul „,cea mai bună dintre lumile posibile” sau ,am făcut tot ce s-a putut”), are o bruscă revoltă morală: „Cum își permit, dom'le, ăștia să interneze un bolnav de Covid pe o secție non-Covid?!”. Morala istoriei este cusută cu ață albă: ce ție nu-ți place, altuia nu-i face.

În filosofia morală, această concluzie poartă numele de ,regula de aur” și poate constitui, singură, un fundament al construirii unui sistem de organizare socială. Ea presupune în primul rând să acceptăm alteritatea (și ceilalţi sunt oameni, ca noi), compasiunea (tratează-1 pe celălalt ca pe fratele tău) și umilința (întoarce și celălalt obraz). Ați recunoscut, probabil, (o parte din) valorile creștine decantate din filosofia stoică, atât de criticate de Nietzsche, dar încă prevalente cel puțin în discursul public național și european. Sfântul Apostol Pavel folosește aceeași regulă de aur pentru a explica noilor comunități creștine cum să se gospodărească. În Epistola către romani, el spune textual: „Pentru că (poruncile): să nu săvârşeşti adulter; să nu ucizi; să nu furi; să nu mărturiseşti strâmb; să nu pofteşti... şi orice altă poruncă ar mai fi se cuprind în acest cuvânt: să iubeşti pe aproapele tău ca pe tine însuţi. Iubirea nu face rău aproapelui; iubirea este deci împlinirea legii." (Rom. 13.9-10).

Dar ce facem atunci când există Corona-sceptici care consideră pentru ei înșiși că este mai bine să nu se protejeze? Sau dintre cei care nu neagă evidența, dar care aleg să parieze pe „,imunizarea de grup” și încearcă să se expună chiar virusului pentru a dobândi imunitate naturală după ce organismul va fi luptat cu (și, evident, învins) boala? Ori, pur și simplu, pentru cei care, punând în balanță viața lor ,normală” cu restricțiile impuse, ajung la concluzia că plusul reluării vieții normale este mai mare decât minusul restricțiilor și aleg să le ignore pe cele din urmă? Practic, este vorba despre un joc de ,ruletă rusească” pe care unii dintre noi și-l asumă (convinşi că vor câștiga) și în care (posibilul) câștig individual pune în umbră faptul că glonțul rămas în pistol îl poate omorî pe cel de lângă noi. Lor le „place” să riște, deci consideră că și ceilalți își pot asuma aceste riscuri.

Am putea utiliza „testul Rawls” pentru a vedea compatibilitatea regulilor cu situația dată. În celebra sa Justice as Fairness, John Rawls propune ca standard de evaluare a unui sistem juridic (dar putem să aplicăm standardul și la un domeniu particular - o ,instituție” ca să folosim limbajul lui Rawls) plasarea unui individ „fără calități” în poziţia de a evalua ,justețea” unei reguli. Prin individ „fără calități” am desemnat un om care (încă) nu știe în ce categorie va fi plasat de valurile vieții ${ }^{1}$. Este „omul obișnuit” înainte de a primi ,eticheta” de om obișnuit. $\mathrm{Nu}$ este individul ideal, pentru că nu este nimic ideal la el decât ideea de reprezentant al speciei umane. Tot ceea ce deține este ,bunul simț” și apartenența la specia umană. Din această poziție, el se plasează sub un ,,voal al ignoranței”, în sensul în care nu știe ce calități (și ce defecte) are el însuși. Poate avea o inteligență peste medie sau sub medie, dar el nu știe; poate fi bogat sau sărac, dar nu o știe; poate fi charismatic sau antipatic, dar nici asta nu știe. Un astfel de individ

\footnotetext{
${ }^{1}$ De aceea am evitat expresia „om fără însușiri” care ar fi fost mai potrivită, dar ar fi făcut o trimitere nedorită la romanul omonim al lui Robert Musil.
} 
este punctul de referință perfect pentru analiza unei reguli care să fie folosită apoi de oamenii ,adevăraţi”.

Cum aplicăm „testul Rawls” în ipoteza Covid-19? Îi adresăm individului nostru despre care nu știm ce calităţi are întrebarea dacă ar considera norma în cauză ,justă”. „Cheia” întrebării stă însă în ipoteză: „cobaiul” experimentului nostru mintal nu știe dacă el are o constituție fizică (sau o poziție socială) care să îl expună la infectare și la dezvoltarea unei patologii agresive sau nu. Este posibil să fie vorba despre un individ „,cu comorbidități” sau un lucrător într-o secție „Covid" dintr-un spital ori un pacient al unui azil pentru bătrâni. Atunci când știi că viața ta este miza ,pariului” pe care îl faci, ai mai fi atât de deranjat de limitarea libertății de mișcare?

Câteva exemple din realitatea cotidiană ne pot ajută să vedem cum putem folosi acest test.

Se vorbește în ultima vreme despre instaurarea unei ,dictaturi medicale" cu toate conotațiile negative pe care termenul îl are într-o societate democratică. Dar nu trebuie să uităm că el este utilizat de medici care se supun ei înșiși acestei „dictaturi” ori de câte ori ,,intră pe secție”. Si nu sunt neapărat ei dictatorii... Virusul este cel care dictează medicilor din secțiile de boli infecțioase să se protejeze, chiar dacă asta înseamnă să lucreze în condiții (extrem de) grele. Ar trebui aceleași măsuri precum cele luate în spitale să fie generalizate și pe străzi? O imagine apocaliptică din filmul Contagion îl prezintă pe personajul interpretat de Jude Law mergând pe străzile pline de oameni infectați purtând în permanență o ,cască” presurizată. Sau este acceptabil să ne (auto)izolăm cu toții în case până când virusul nu va mai găsi o gazdă în care să se multiplice? Probabil că un om rezonabil (omul nostru fără calități) va considera aceste măsuri ca fiind prea extreme.

Pe de o parte, actuala organizare socială nu poate rezista fără ca anumite activități să fie realizate „la foc continuu” de oameni care ies din casă și se duc la serviciu (gândiți-vă la serviciile de pompieri, de electricitate, apă și gaze pentru a menționa doar câteva). Nu am menționat (tocmai) serviciile medicale pentru că acolo se iau (de regulă) măsuri extreme de protecție. Dar și acolo vedem pe zi ce trece o „segregare” între specializările „Covid” și „,nonCovid”, iar separarea are în vedere „triajul epidemiologic” menit să se asigure că în secțiile „,nonCovid” nu ajung pacienți ,suspectați”. De aici rezultă faptul că nici măcar toți medicii nu ar accepta în mod rezonabil să-și ia măsurile extrem de protecție implementate de medicii din secțiile de boli infecțioase. Iar protecția ,pasivă” de tipul nu merg la serviciu (sau nu am contact fizic cu alte persoane) s-a dovedit la fel de greu de implementat. Protestele (justificate) determinate de refuzul de internare a pacienților cu boli cronice a demonstrat că nu putem „suspenda” prestarea de servicii „faţă-în-față”.

Pe de altă parte, implementarea unor măsuri extreme de protecție sanitară se dovedește nepractică din mai multe puncte de vedere. În primul rând, este greu să transferi costurile materialelor sanitare (exclusiv) către populaţie. Justificarea pare una raţională: este interesul individului să nu se îmbolnăvească (să-și protejeze viaţa proprie) și, deci, este obligația sa să se îngrijească de aceasta. Dar, așa cum această pandemie a demonstrat, este greu pentru fiecare persoană să-și procure toate mijloacele de protecție. Uneori este dificil să se asigure o alimentare constantă cu stocurile necesare (mai ales în debutul pandemiei, caracterizată de panică în masă) Alteori este dificil să suporți costul fizic al acestor materiale, mai ales atunci când creșterea bruscă a cererii denaturează prețurile. De multe ori este greu să controlezi calitatea materialelor puse pe piață. Aici statul ar trebui să fie mai mult decât un simplu emitent de norme obligatorii. El ar trebui să acționeze pentru a remedia toate aceste disfuncționalități. Statul ar trebui să asigure (măcar) stocurile de urgență pentru a acoperi necesarul în perioadele de panică. Statul ar 
trebui să instituie un control (temporar) al prețurilor pentru a asigura că nu există variații oportuniste. Tot statul ar trebui să certifice calitatea materialelor puse în vânzare. În același timp, însă statul ar trebui să asigure punerea la dispoziție de materiale sanitare pentru persoanele vulnerabile prin distribuirea lor gratuită. Dar, cel mai important, statul trebuie să asigure informațiile cu privire la tipul de materiale necesare pentru protecția individuală și modul (corect) de folosire.

Ținând cont de decizia justă a omului fără calități, oare un asemenea individ (ipotetic) ar considera exagerat să (își procure și să) poarte mască de protecție în toate situațiile în care interacționează cu alte persoane? Oare nu i s-ar părea o măsură rezonabilă să poarte mască inclusiv când merge pe stradă, unde în mod inevitabil se intersectează la distanțe sub 2 metri cu alte persoane? În schimb, va fi greu de convins să accepte să nu mai iasă din casă pentru o perioadă lungă de timp. Ar putea însă să înțeleagă necesitatea de a nu ieși din casă la începutul pandemiei, pentru o perioadă rezonabilă, necesară autorităților pentru a pune la punct un sistem care să permită apoi o „relaxare” a restricțiilor de circulație. Acest „răgaz” nu trebuie privit în sensul unei pasivități administrative: stăm în casă și va trece pandemia fără să ne afecteze (prea tare). El trebuie folosit de către stat pentru a înțelege cerințele medicale, a găsi soluții pentru prevenție și (aici suntem noi deficitari) a le implementa în mod concret. Nimeni nu poate evita panica din primele zile ale pandemiei și lipsa de materiale sanitare pe care nimeni nu le anticipa. Dar am văzut că după prima lună au reapărut făina și drojdia în magazine, măștile s-au „democratizat” și se găsesc peste tot la prețuri rezonabile, iar gelul antibacterian a revenit în toate magazinele. Acum trebuie să le folosim.

Nici izolarea totală nu este o soluție reală (cum a fost, de exemplu, în cazul Taiwanului, a Noii Zeelande, care sunt insule) pentru România. Dar o procedură clară de control la frontieră cum a implementat Grecia, de exemplu, se putea găsi în perioada de „,carantină”. De asemenea, conștientizarea riscurilor și, mai ales, a obiceiurilor din vremuri normale care pot deveni riscante în noul context se poate face prin educație (adică prin explicaţii raționale urmate de soluții alternative). Îmi amintesc că, în luna ianuarie 2020, unei studente chineze proaspăt întoarse din vacanța de iarnă petrecută în China, un profesor i-a refuzat accesul în sala de clasă. Cazul a fost tratat ca o abatere disciplinară pentru profesor. Mă întreb dacă între timp atitudinea nu ar trebui nuanțată. Nu în sensul instituirii unei paranoia generalizate față de „străin”. Ci în sensul adoptării unor proceduri (nediscriminatorii) prin care orice persoană venită din afara țării trebuie să treacă printr-o verificare minimă (test de infectare). Este iluzorie ideea unei izolări de 14 zile pentru toate persoanele care intră în țară în situația în care nu există locuri de ,cazare” puse la dispoziție de autorităţi sau acestea, dacă ar fi, sunt refuzate de candidați. În schimb, este posibilă instituire a obligativitătii testării, dublată însă de existența unor facilități de testare la locurile de trecere a frontierei pentru cei care nu au apucat să se testeze la plecare, cu condiţia ca rezultatul testului să vină într-un termen scurt.

Se tot vorbește despre cum va începe școala în septembrie, dar nu văd eforturi reale de a găsi soluții concrete. Este evident că vom începe tot în condiții de pandemie, dar acum nu mai avem scuza surprizei din martie. Ar trebui ca acei profesori care nu au reușit să se adapteze „din mers" să urmeze cursuri specializate de învăţământ online, organizate în mod gratuit de către stat. Ar trebui ca administrația să aibă deja asigurate stocurile de materiale sanitare în școli și să generalizeze planurile de acces și distanţare pe care le-au implementat (temporar) în timpul examenele naționale din această vară. $\mathrm{Nu}$ am văzut încă discuții pe aceste teme... În schimb, am văzut un Raport guvernamental care spune în multe cuvinte că fiecare unitate de învățământ va trebui să se descurce singură, iar dacă se întâmplă ceva grav, vina va fi exclusiv a ei, pentru că nu 
a implementat toate măsurile necesare; un fel de „la limita evitării oricărui pericol” din vechiul Cod rutier.

Dar poate cea mai îngrijorătoare tendință este cea a ignorării regulilor. În ciuda tuturor clișeelor despre incapacitatea românilor de a respecta reguli (stricte), perioada de stare de urgență ne-a demonstrat că românii respectă regulile cel puțin la fel de mult ca și ceilalți europeni. Diferența este însă una de cultură a regulii. Atunci când vezi că tu respecți regulile, iar cei care le-au adoptat nu o fac, începi să te întrebi dacă nu cumva greșești tu („ești mai fraier”). Atunci când tu respecți regulile în mod temporar pentru a da ocazia administraţiei să se organizeze pentru a avea un plan de acțiune pus la punct după ridicarea urgenței și apoi vezi că ți se spune să te descurci şi tu cum poți, te întrebi de ce a mai fost nevoie să te sacrifici la început. Atunci când tu continui să respecți noile reguli de după urgență dar vezi în jurul tău că mulți colegi nu o fac, te întrebi ce rost mai are.

Respectarea regulilor este o cursă de maraton, iar nu una de sprint. Nu este suficient să respectăm regulile pentru o perioadă limitată și apoi să revenim la o situație în care fiecare se descurcă așa cum poate. Această criză ar trebui să ne învețe să respectăm regulile pe termen lung. De partea cealaltă, statul trebuie să învețe și el să adopte reguli care să poată fi respectate pe termen lung. Statul nu (mai) trebuie să fie reactiv și să schimbe regulile des pe ideea că rezolvă doar o problemă punctuală (și temporară) și oricum lumea nu va respecta (mult timp) regula cea nouă. Sunt totuși legi care au rezistat (în România) mai mult de 100 de ani fără a se modifica (substanțial). Și au fost respectate. Poate pentru că lumea le-a internalizat și nu se mai gândește la ele ca legi, ci ca obiceiuri?

De obicei evită să încerc să formulez concluzii pentru că este de preferat ca fiecare individ (cititor) să ajungă la propriile concluzii. Dar mă întreb dacă un sistem politicoadministrativ bine (re)structurat nu ar trebui să ia în considerare o consultare populare serioasă (nu un referendum, ci o dezbatere publică) în care să pună în discuție un set de idei de gestionare a crizei pe care să le justifice rațional și să accepte și sugestii din partea „publicului” pentru a decanta apoi un plan coerent de măsuri care să fie și logice din punct de vedere științific, dar și acceptate de către adresanți. Dar pentru asta ar trebui să elaboreze înainte o strategie bine fundamentată (şi să o explice), iar apoi să aibă mecanismele care să poată permite preluarea, prelucrarea și sistematizarea ideilor „din piață”.

Materialul a fost publicat în revista online a Facultății de Drept, $\underline{\text { AUBD - Forum Juridic nr. }}$ $\underline{2 / 2020 .}$ 